\title{
Simulated provocations: A hypermedia radio theatre for reflection on classroom management
}

Mattias Arvola, Marcus Samuelsson, Mathias Nordvall and Eva Ragnemalm

The self-archived postprint version of this journal article is available at Linköping University Institutional Repository (DiVA):

http:// urn.kb.se/ resolve?urn=urn:nbn:se:liu:diva- 147331

N.B.: When citing this work, cite the original publication.

Arvola, M., Samuelsson, M., Nordvall, M., (2018), Simulated provocations: A hypermedia radio theatre for reflection on classroom management, J ournal Simulation \& Gaming, 49(2), 98-114.

https:// doi.org/ 10.1177/ 1046878118765594

Original publication available at:

https:/ / doi.org/ 10.1177/ 1046878118765594

Copyright: SAGE Publications (UK and US)

http:// www.uk.sagepub.com/home.nav 
Simulated Provocations:

A Hypermedia Radio Theatre for Reflection on Classroom Management

Mattias Arvola ${ }^{1}$, Marcus Samuelsson ${ }^{2}$, Mathias Nordvall ${ }^{1}$, and Eva L. Ragnemalm ${ }^{1}$

${ }^{1}$ Linköping University

${ }^{2}$ University West

Author Note

This research has been supported by the Swedish Research Council [reference number 721-2011-4741].

Correspondence should be addressed to Mattias Arvola, Department of Information and Computer Science, Linköping University, 58183 Linköping, Sweden.

Contact: mattias.arvola@liu.se 


\begin{abstract}
Background: Learning to manage a classroom is a difficult but important part of teacher education. Earlier research on simulations for learning classroom management has highlighted the difficulty of supporting reflection.

Purpose: This case study explores and evaluates the design of a simulation for student teachers' reflection on classroom management.

Design: The design process resulted in the scenario-based SIMPROV simulation, which was made in the form of a hypermedia radio theatre that students go through in pairs or triads. Authoritarian, authoritative, democratic, and compliant leadership styles were built into the choices student teachers made.
\end{abstract}

Evaluation: The simulation was evaluated in two courses where the participants' level of reflection and perceived knowledge improvement was measured using a questionnaire. Forty-three first-year student teachers, 48 third-year student teachers, and 38 of the student teachers' mentors participated in the evaluation.

Results: The results indicate that participants engaged in reflection and understanding to a high degree, and only to a low degree in critical reflection or habitual action.

Conclusions: The conclusions are that the scenario-based simulation designed as a hypermedia radio theatre supported knowledge improvement, understanding, and reflection and that social interaction during and after simulation sessions was an important feature. 
Keywords: Interaction design, simulation/gaming, reflection, learning, teacher education, classroom management 
Simulated Provocations:

A Hypermedia Radio Theatre for Reflection on Classroom Management

A vital part of becoming a teacher is learning how to manage a classroom. However, student teachers ${ }^{1}$ only have a limited amount of time to test their knowledge of this area during placements at schools (Jones, 2006). Furthermore, student teachers often leave their teacher training programme with a feeling of being unprepared for managing the classroom and resolving conflicts (Samuelsson \& Colnerud, 2015). A teacher's response to this lack of preparedness may be the use of punishment, despite its well-known ineffectiveness (Lewis, Romi, Katz \& Xing, 2008; Emmer \& Sabornie, 2014). Thus, other ways of gaining the necessary experience need to be sought. One way of providing experience in classroom management is to use simulations. That idea has been around since the 1980s (Brophy, 1988). The aim of this case study is to explore and evaluate the design of a simulation for student teachers' reflection on classroom management.

${ }^{1}$ The term 'student teacher' here refers to a student on an undergraduate university teaching program in any year of the program. In Sweden these students spend (limited) time placed at schools from the first year. 


\section{Classroom Simulations}

Early classroom simulations consisted of manually controlled film sequences and printed materials. Research on such simulations indicated a change in the way principles of teaching were being learned (Kersh, 1965). The learning was transferrable also to the actual classroom. Because of this change, there was a more rapid development of teaching capabilities and capacity of assuming full responsibility for a class. A more recent simulation for learning classroom management, developed and studied in an action-research project by Edman Stålbrandt (2013), used a similar approach with dilemmas presented in non-interactive animated sequences of sound, text and images. Reflection was scaffolded through questions for group discussion after simulation sessions. Edman Stålbrandt's results indicated that sound and speech carried emotional content well, while text carried facts better. She also noted that reflection was difficult for participants, and she stressed the importance of the educational structure surrounding the simulation. Similar in approach to Edman Stålbrandt's simulation is the scenario-based simulation for reflection on diversity issues developed by Manburg, Moore, Griffin, \& Seperson, (2017). Technically, it provides on-line written scenarios, dealing with the planning of interventions. It focuses on teamwork where student teachers jointly choose interventions. Reflection was hence facilitated not only after simulation sessions, but also during simulation. 
Another recent simulation for learning classroom management has used virtual reality worlds with avatars, which student teachers have found to be useful for learning to "think on their feet" (Mahon, Bryant, Brown, \& Kim, 2010, p. 121). SIMSCHOOL is a simulation intended for learning to create lesson plans, taking attendance, and completing individualised education plans (Badiee \& Kaufmann, 2014; 2015). Student teachers work individually with SIMSCHOOL to apply their knowledge to various teaching scenarios. It has up to 25 interactive agents to make the simulation more lifelike. Participants can also engage in interactive stories with a branching structure, where they must make decisions, justify them, and experience the consequences as the stories develop. This has also been used to cater for diversity among pupils (Rayner \& Fluck, 2014). There are no features designed to support reflection during simulation sessions. An additional simulation for developing teaching skills for inclusive classrooms is TEACHLIVE (Dieker, Rodriguez, Lignugaris/Kraft, Hynes, \& Hughes, 2014). It offers student teachers personalized learning experiences and suspension of disbelief in a realistic classroom and can contribute to development of self-efficacy (Bautista \& Boone, 2015). The student teacher interacts with five virtual pupil characters in a classroom that is projected onto a wall. A camera captures what the student teacher is doing, and the characters are controlled by a trained orchestra leader from a distance (Hughes, Nagendran, Dieker, Hynes, \& Welch, 2015). Support post-action for reflection is given through both automatic data capture, such as time spent in proximity to each 
pupil or time spent talking, and manually tagged events, such as the number of highlevel questions, specific and general praise, and time from question to answer (Hughes, et al., 2015). The purpose of both SIMSCHOOL and TEACHLIVE is to facilitate the effectiveness of student teachers' teaching methods.

\section{Fidelity and Validity of Simulations}

The fidelity of a simulation is the degree of similarity between the simulation and the real world. A natural assumption seems to be that a high-fidelity simulation would lead to better learning, but this is not necessarily the case. For instance, Kersh (1965) compared films shown on small and large (life-size) screens (where life-size would be higher fidelity than a small screen), finding no difference in effect, and Toups, Kerne, Hamilton, and Shahzad (2011) implemented a game that had no similarity to the target context, yet found significant transfer of the target skill.

A simulation for learning can be said to have four aspects of validity (Feinstein \& Cannon, 2002). Application validity is when intended students learn what they are supposed to. For example, if third-graders are supposed to learn about the solar system, and third-graders actually learn about the solar system from playing a game, then the game has application validity. Representational validity is when the simulation represents the functionally critical aspects in a believable way. That is, when the simulation represents, for example, the movements of the planets convincingly. Internal validity is when the students can use it and learn from it. For instance, when they can 
navigate the simulation of the solar system and use it to answer study. External validity is when the simulation brings about learning results that are transferrable to other situations. An example, would be when the third-graders gain knowledge that can be used outside the simulation to reason about how the solar system works.

\section{Reflection}

Some simulations for teacher education make reflection a part of the educational experience while others stress quick reactions (thinking on your feet). Edman Stålbrandt (2013) noted that reflection was difficult for her participants. Reflection is therefore an important aspect of the present study, and our project aimed at developing a simulation for reflecting on classroom management.

Reflection is critical to finding different points of view. Without reflection, you are performing habitual action without much conscious thought and no learning takes place. This is what Schön (1983) refers to as knowing-in-action, and it is learning that is based on rehearsal. With some more explicit knowledge you engage in comprehension or understanding, making use of earlier knowledge, but remaining within the frames of certain perspectives and without relating it to other things or situations (Bloom, 1956). This kind of knowledge includes much of the knowledge and rule-based skills students learn at university. With reflection, beliefs are considered in relation to what the basis for the beliefs are and what the consequences are. Assumptions are questioned, and experiences are examined to gain new understanding and different points of view 
(Mezirow, 1997). Critical reflection is an even more profound and uncommon level of reflection. It involves becoming aware of why we think and act the way we do, questioning the habits of mind and the premises for our actions and thoughts (Mezirow, 1997). Critical reflection is about recognising we are governed by belief systems that we have not been aware of. Conventional thinking and deeply rooted beliefs are hard to change, and critical reflection is therefore difficult to attain (Kember, Leung, Jones, Loke, McKay, Sinclair, Tse, Webb, Wong, Wong and Yeung, 2000). Thus, we can identify four levels of reflection: habitual action, understanding, reflection, and critical reflection (Kember, et al., 2000).

\section{Research Problem and Case Study Method}

The research problem for this case study involves both the simulation design and the evaluation of reflection and perceived knowledge improvement. This means that the research questions are:

- How does one design a simulation to support student teachers' reflection on classroom management? (RQ1)

- What level of reflection do student teachers using the simulation engage in? (RQ2)

- What degree of knowledge improvement do the student teachers experience? (RQ3) 
The case study is descriptive, and it is qualitative in nature for the design question (RQ1), and quantitative in nature in the evaluations (RQ2 and RQ3). This means that the case study incorporated a mixed-methods approach, with an explorative sequential design (Cresswell \& Clark, 2018). We first explored the design qualitatively through several iterations of prototyping, before putting the resulting solution to test in courses for student teachers.

The following section describes the design of the simulation, and the motivations for the major design decisions. This section provides an answer to the first research question (RQ1). The section thereafter details the evaluation method and results, and it provides answers to the second and third research questions (RQ2 and RQ3).

\section{Design of the Simulation}

The design and development of the simulation for student teachers' reflection on classroom management used an iterative process where early iterations focused on general content and one single medium, and further iterations added more media and more detail, creating multimedia simulations. This simulation was named SIMPROV, short for Simulated Provocations. 


\section{Leadership Styles}

The educational content of SIMPROV focuses on four leadership styles based on Lewin, Lippit, and White's (1939), and Baumrind's (1971) research on social climate, leadership, and fostering styles in classrooms. In this context they are dubbed authoritarian, authoritative, democratic, and compliant (Ragnemalm \& Samuelsson, 2016).

Authoritarian: In this leadership style the teacher has all the power and makes demands on the pupils, who have no influence over the situation. The teacher maintains a distance from the pupils and is aloof from them. The teacher does not show the pupils any plan for the lesson. The pupils are expected to respect the teacher who shows no consideration for the pupils. The teacher takes command and demands the pupils' attention in a loud voice. The teacher maintains control by demanding obedience and does not interact with pupils. The body language is tightly controlled and indicates that the teacher is the leader. The teacher criticizes pupils openly by name and speaks in terms of what he or she expects of the pupils.

Authoritative: In an authoritative leadership style, the teacher may share the power, and the pupils are influenced by the teacher's permission, while the teacher guides them. A certain distance is kept between teacher and pupils. The teacher shows the pupils what the plan for the lesson is. Respect between pupils, and between pupils and teachers is mutual and expected. The teacher starts the lesson by asking the pupils 
to pay attention. The body language is controlled, showing that the teacher will guide the pupils, and showing openness and interest in the pupils. The teacher describes the content of the lesson and communicates this in terms of what both pupils and the teacher will do. The teacher chats with the pupils and includes all of them. Care and faith in pupils' capabilities are expressed.

Democratic: In this leadership style, the power is divided between teacher and pupils, and the influence is explicitly distributed. The relationship between teachers and pupils is close, or even friendly. The plan for the lesson is agreed upon and made visible. The respect between teachers and pupils is mutual and intentionally nurtured. The teacher gets the attention of the class with a focus on the beginning of the lesson. The teacher's body language is relaxed and he or she guarantees that the responsibility is shared, showing that pupils and teacher do this together. The teacher reminds pupils about agreements and asks pupils to explain things. The teacher expresses care and faith in their capabilities.

Compliant: In the compliant leadership style, the power is in the pupils' hands. The teacher has no control over the situation, and no plan for the lesson is made visible for the pupils. Distance is kept, and respect is neither expected nor given. The teacher makes vague attempts to start the lesson, waits and lets the pupils silence each other. The teacher seems uncomfortable and uncertain and indicates that the pupils have to manage the lesson themselves. Messages are marked by insecurity and ambiguously 
directed to the pupils. The teacher does not provide any care for the pupils and shows no faith in them.

\section{Scenarios}

The four leadership styles described above were built into SIMPROV. The desire to stimulate reflection during simulation led to the decision to halt the simulation at certain points, thus selecting a scenario-based simulation technique. This means that the simulation was constituted of predefined scenes strung together by a restricted set of actions as opposed to a computational model of a classroom with autonomous pupil agents. Construction of computational models of pupil behaviour would have required identification of ranges of body movement, facial expressions, and verbal behaviour that portray exactly the intended activities and emotions and nothing else, in order to provide believable situations with the intended cues and no unintended cues. The complexity of the problem of constructing believable computational models of pupil behaviour was therefore an additional factor in this design decision.

The simulation consists of scenarios of everyday problematic classroom situations that teachers often need to manage in their classroom. Each scenario is presented with an introduction that describes a classroom situation, and it is followed by four mutually exclusive choices that implicitly embody the four leadership styles. Making a choice will then take the scenario into a brief sequence of events and new choices within the chosen style before all paths lead to a new situation where the four 
styles are again available. The student teachers can always go back if they want to try another course of action.

The scenarios are descriptive rather than normative, which means that the student teachers cannot rely on one answer being obviously the right one. However, some consequences of actions are unwanted or less desirable than others. The intention behind that design decision was to introduce some uncertainty to promote student teachers' reflection, by forcing them to evaluate the results of their choices. Therefore, in order not to suggest that one leadership style is inherently always better than another, no scores are kept, and no points are given. However, the choices student teachers made were recorded and presented in information graphics at the end of a session.

The content of the scenarios was based upon research on classroom management that had been conducted by the domain expert and others in earlier research (cf. Wedin, 2007; Bartholdsson, 2007; Samuelsson, 2008; Wester, 2008; Karlberg, 2011; Samuelsson, 2013). They were made as authentic as possible, so student teachers could make choices that felt appropriate, and use them in discussions with peers, mentors, and teacher educators. The representational validity of scenarios has been assessed by having four teenagers, four teachers and four teacher educators inspect a manuscript of the content and an early beta-version of the first iteration of the simulation. In both cases this was followed by a review of their written reflections during interviews (Ragnemalm \& Samuelsson, 2016). 


\section{Three Design Iterations}

The first iteration of SIMPROV focused on shaping the content, selecting educational focus, and choosing simulation technique. The first iteration was a hypertext-based simulation where situations in the scenarios were described in text only, and the users were to choose alternative actions. The age and gender of the teacher was left undefined to facilitate identification with the role. It was decided to support reflection and discussion by having student teachers interact socially and go through the simulation in pairs or triads. The emphasis of the first iteration was getting the flow of events and texts of the scenarios right, so student teachers would find them authentic. Each page also provided a link going back in the structure to support exploration. The application validity was assessed by determining that the student teachers could perceive the critical aspects of classroom management in the simulation (Ragnemalm \& Samuelsson, 2016). Furthermore, it was assessed as plausible and valuable for learning classroom management, as well as exploratory and playful (Nordvall, Arvola \& Samuelsson, 2014).

The second iteration added still images to the text and one, less interesting, scenario was omitted. Adding still images meant that details regarding the gender and age of the portrayed teacher became specified.

The third iteration added sound, mostly voice, to illustrate tone of voice and facilitate engagement. Earlier research has shown that sound is an important carrier of 
information and engagement for classroom simulations (Edman Stålbrandt, 2013).

Informal feedback from student evaluations of the first and second prototype supported this. The basic structure of the hypertext was preserved, but the textual presentations were reduced and largely replaced with sound (voices and sound effects). The simulation then took the form of a hypermedia radio theatre with complementary text and still images (Figure 1). Each situation here consists of a drawing, a short text introducing the situation, with additional information provided by an audio clip. The four choices also have a short text label and an audio clip.

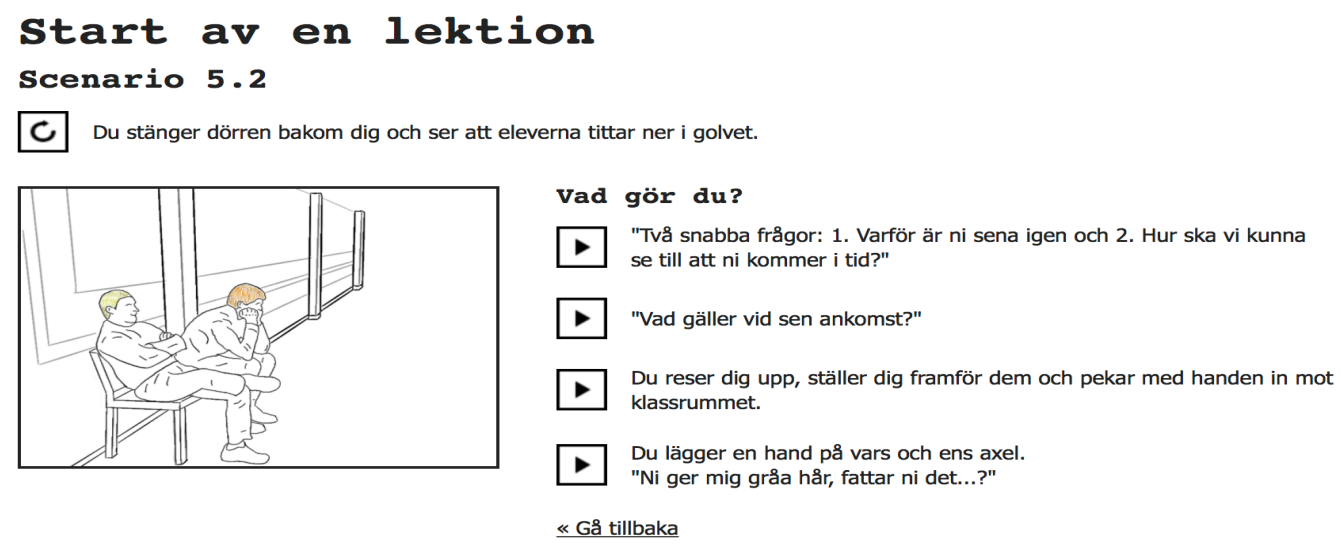

Figure 1. SimProv Iteration 3 - hypermedia radio theatre. The user starts playing the audio for the event, and can also replay it, or continue by listening to the four alternative courses of action before proceeding with one of them ("Gå vidare »") or go back ("“ Gå tillbaka"). Translated from Swedish, the scenario states: "Beginning of a class. Scenario 5.2. You close the door behind you and see that the students look down at the floor. 
What do you do? [Alterative 1:] "Two quick questions: 1. Why are you late again? and 2. How can we make sure you get to class on time?" [Alternative 2:] "What is the protocol for late arrival?" [Alternative 3:] You get up, stand in front of them and point inwards to the classroom. [Alternative 4:] You place a hand on their shoulders. "You give me grey hair; do you realize that...?"

Above, we characterized SIMPROV as hypermedia radio theatre. Hypermedia can be defined as an "an augmentation of hypertext and multimedia" (Moos \& Marroquin, 2009, p.266). SIMPROV is multimedia in its combination of representations in multiple media formats, and it is hypertext in its nonlinear design, with hyperlinked information nodes that permit the user to take different paths through the material. SIMPROV is not only hypermedia, it also creates a hybrid form by borrowing elements from radio theatre. Radio was used in education as early as the 1920s (Grise, Epstein \& Lukin, 1974; Reid \& Day, 1942). The earliest examples of drama on the radio appeared in the 1920s and were like listening in to a play at the theatre (Hand \& Traynor, 2011). Radio drama, or radio theatre, eventually developed into its own media form. SIMPROV borrows from the radio theatre media format by having voice actors acting out the scenarios in hyperlinked audio clips.

The audio clips made it possible to reduce the focus on the text, as well as communicate not only what people said, but also how they said it with more nuance. 
This again highlighted some aspects which had been left undecided in earlier prototypes, such as the tone of voice in certain utterances. Also, in a few cases this created slightly different impressions between the teacher's behaviour as written in the text compared to how it was acted out in the radio theatre. This iteration of SIMPROV also visualized the choices the user had made in information graphics at the end of the session.

\section{Evaluation of the Simulation}

In the present study, the SimProv Iteration 3 - the hypermedia radio theatre - was evaluated in an assessment of the student teachers' level of reflection and subjectively experienced knowledge improvement in two different courses, described below.

\section{Evaluation Method}

The specific questions for the evaluation were what levels of reflection the participating student teachers engaged in, and to what extent the student teachers perceived that they had improved their knowledge in classroom management.

\section{Test Courses}

Two different courses, with different students, provided an opportunity to validate the evaluation results. In the second course, mentors working at schools were also included.

The first course was called Educational Sciences 5, Social Relations and Teacher Leadership. The participants were student teachers in their third year of study 
to be primary school teachers (corresponding to elementary school teachers in the USA). The course consisted of a series of lectures and seminars on topics like bullying, conflicts in the classroom, and management of the classroom. There was one simulation session during the last week of the course, to apply the course content. There were 48 student teachers participating in this course.

The second course was called Social Sciences, Teaching Practice, and it included two weeks of placement at a school. These students were in their first year of their teacher education, studying to be primary school teachers. The course had one simulation session. A lecture about classroom management was given before the simulation. It covered the areas of the way teachers establish sustainable structures, rules, routines, respectful relations, a good classroom climate, clear expectations and motivations, and reasonable disciplinary interventions. Forty-three student teachers from the course participated in the evaluation. In addition, 38 mentors (experienced teachers at primary schools) participated in the evaluation.

After the simulation sessions, participants were instructed to discuss the events in the simulation in pairs or triads: how they felt and what they thought about it; what they could learn from it; what concepts they used; what they could have done differently; and what they would have done if it had happened in a real classroom. Finally, in course two, all participants gathered in a lecture hall for a joint concluding 
session. Participation in the evaluation of SIMPROV was voluntary and anonymous. Informed consent was obtained from all participants.

\section{Level of Reflection}

The level of reflection was measured using a questionnaire developed by Kember et al. (2000). It measures the extent to which participants perceive themselves to have acted on the four levels of reflection: habitual action, understanding, reflection, and critical reflection. It has been shown to have acceptable reliability in measuring the four constructs. The questionnaire has four items for each level of reflection and the participants mark to what extent they agree on a scale from A to E. The points from the four items were added for every participant $(A=5, B=4, C=3, D=2$, and $E=1)$. This means that every participant received a score of between 4 and 20 on all four levels of reflection. Then, the median was calculated for each level of reflection, and the difference between levels of reflection were tested using the Wilcoxon Signed-Rank test, after determining non-normality of data using Shapiro Wilk W. Differences between groups of participants were tested using the Mann-Whitney U test.

In all, 18 significance tests were made on the same data, which meant that there was an increased risk of getting significant results by chance. However, this is an explorative study of novel design solutions, and it would therefore be worse to miss real significant differences than it would be to find false ones. We therefore decided not to use the rather conservative Bonferroni correction, since it potentially can lead to a high 
rate of false negatives, and the number of tests on the data is relatively few. Instead, we kept the risk of false positives in mind during the interpretation of results, especially for borderline cases.

\section{Knowledge Improvement}

Subjectively perceived knowledge improvement was measured using the sub-dimension for that purpose in the EGameFlow questionnaire (Fu, Su \& Yu, 2009). The validity and reliability of the questionnaire has been evaluated as satisfactory for use with university students. Perceived knowledge improvement means that the participant rates to what extent that simulation contributes to the his or her knowledge. The sub-dimension in the questionnaire has five items and uses a 7-point Likert scale. The median for the five items in the Knowledge Improvement sub-dimension of EGameFlow was calculated, after determining non-normality of data using Shapiro Wilk W.

\section{Evaluation Results}

Two third-year student teachers, two first-year student teachers, and six mentors were removed from the reflection data set, since their questionnaires were incomplete. One first year student's and two mentors' knowledge improvement questionnaires were also removed due to incomplete responses. This resulted in $N=119$ for the reflection data set (first-year student teachers $n=41$, third-year student teachers $n=46$, mentors $n=$ 32 ), and $N=126$ for the perceived knowledge improvement data set (first-year student teachers $=42$, third-year student teachers $=48$, mentors $n=36$ ). 


\section{Level of Reflection}

The reflection data was skewed and not normally distributed (tested using Shapiro Wilk W). In Table 1, the scores for the different levels of reflection (habitual action HA, understanding $\mathrm{U}$, reflection $\mathrm{R}$, and critical reflection) are presented for the first-year student teachers, the third-year student teachers, the mentors, and all of them in total. The median score and interquartile range on every level of reflection is reported for each group of participants. The lowest possible score on a level of reflection was 4 and the highest possible was 20 .

Table 1

Median score and interquartile range (Q1-Q3) on habitual action (HA), understanding (U), Reflection (R), and Critical Reflection (CR) for the different groups with the number of participants (n).

\begin{tabular}{lccccc}
\hline Group & $\mathrm{n}$ & HA & $\mathrm{U}$ & $\mathrm{R}$ & $\mathrm{CR}$ \\
\hline 1st year & 41 & $11(8-12)$ & $15(13-17)$ & $18(16-19)$ & $13(9-16)$ \\
3rd year & 46 & $10(8-12)$ & $14(12-16.75)$ & $17(15.25-19$ & $12(9-14)$ \\
Mentors & 32 & $12(6.75-13)$ & $16(14-17)$ & $18(16.75-19)$ & $10(7.75-11.5)$ \\
Total & 119 & $11(7.5-12)$ & $15(13-17)$ & $18(16-19)$ & $11(9-14)$ \\
\hline
\end{tabular}


The results in Table 1, show that the interquartile ranges between the different levels of reflection overlap. There are, however, also differences between how much participants engaged in the different levels of reflection. The participants did not engage in habitual action and critical reflection, to the same extent as understanding and reflection. Habitual action scored the same median as critical reflection but had lower interquartile range.

Pairwise comparisons between the levels of reflection for all participants using a Wilcoxon Signed-ranks test indicated there was a difference between the total scores for:

- $\operatorname{Reflection}($ Median $=18)$ and Understanding $($ Median $=15), z=-7.50$, $p<.001$, with a large effect size $(r=.53)$.

- Reflection $($ Median $=18)$ and Critical Reflection $($ Median $=11), z=-9.23$, $p<.001$, with a large effect size $(r=.61)$.

- Reflection $($ Median = 18) and Habitual Action (Median=11), z= -9.43, $p<.001$, with a large effect size $(r=.61)$.

- Understanding $($ Median $=15)$ and Critical Reflection $($ Median $=11), z=-$ $7.77, p<.001$, with a large effect size $(r=.53)$.

- Understanding $($ Median $=15)$ and Habitual Action $($ Median $=11), z=-9.23$, $p<.001$, with a large effect size $(r=.56)$. 
- Critical Reflection (Median $=11)$ and Habitual Action $($ Median =11), $z=-$ $2.30, p=.021$, with a small effect size $(r=.15)$.

These results show that the participants engaged most in reflection, compared to understanding, critical reflection, and habitual action. They also scored higher on understanding than they did on critical reflection and habitual action. Finally, they engaged in a little more critical reflection than in habitual action, but given the multiple tests there is a risk that this difference was a false positive.

Pairwise comparisons of the levels of reflection between first year students, third year students, and mentors using Mann-Whitney tests indicated the following differences:

- Third-year student teachers' Understanding (Median =14) and mentors' Understanding (Median $=16), U=520, z=-2.19, p=.029$, with a small effect size $(r=.25)$.

- First-year student teachers' Critical Reflection (Median =13) and mentors' Critical Reflection (Median $=10), U=444.5, z=2.35, p=.019$, with a small effect size $(r=.27)$.

The distributions were approximately normal, and therefore, the $z$-score was used instead of $U$. The results show that mentors engaged in more understanding than thirdyear students did, and first-year students engaged in a little more critical reflection than 
mentors. This suggests that first-year students had more revelations than mentors, and mentors understood more new aspects or features of the situation than third-year students. However, these differences may be due to multiple tests on the same data. No other significant differences were found between groups.

\section{Knowledge Improvement}

The data for the perceived knowledge improvement was, just like the data for reflection, skewed and not normally distributed (again tested with Shapiro Wilk W). The median of the perceived knowledge improvement for all participants $(N=126)$ was 6.55 , $(Q 1=6, Q 3=7)$ on the seven-point Likert scale. Surprisingly, there were no observed differences in perceived knowledge improvement between the three groups of participants, but it could be due to a ceiling effect, given how high they rated the simulation on knowledge improvement.

\section{Discussion}

The most important contribution of the Simulated Provocations project is the design outcome in the form of SIMPROV. That is, a simulation that can be used by student teachers to reflect on classroom management. This is important, since many student teachers do not feel that their teacher education programme equips them for managing difficult classroom situations, and many practicing teachers leave their teaching career after only a few years in the profession for the very same reason (Samuelsson \& Colnerud, 2015). 
The evaluation of SIMPROV showed that the participants scored high on reflection $($ Median $=18)$. This means that our participants examined experiences, questioned their beliefs and assumptions, and considered the consequences of these beliefs, which can give rise to changes in points of view and new understanding (Mezirow, 1997). Edman Stålbrandt (2013) noted that reflection was difficult for participants that used her simulations for learning classroom management, but her simulations were not interactive and did not allow student teachers to play around with and explore the scenarios. However, the participants who played SIMPROV did not engage in critical reflection (Median =11). Although, first-year students engaged in slightly more critical reflection than their mentors did. This means that they to a small degree became aware of the reason they thought and acted the way they did and questioned their habits of mind and premises for actions and thoughts (Mezirow, 1997). Supporting such radical changes in how one looks upon a phenomenon would indeed be a worthy challenge for simulation-based learning. The evaluation results also showed that the participants engaged in understanding (Median $=15)$. Mentors engaged in slightly more understanding than third-year students did. Engaging in understanding means that the participants made use of earlier theoretical and rule-based knowledge, while remaining within a frame of mind (Bloom, 1956). All participants also scored high on knowledge improvement (Median $=6.55)$, on that subscale of the EGameFlow 
questionnaire (Fu, Su \& Yu, 2009). This suggests that they also felt that they learned from playing the simulation.

\section{Limitations}

The fidelity of the SIMPROV increased from iteration 1 to iteration 3 with the addition of images and sound, but the level of fidelity remains low. The simulation does not resemble a classroom with actual pupils, and reading, listening, and looking at a screen while discussing is not at all like being in the classroom making decisions in real time. This means that it can be said to have low representational validity (Feinstein \& Cannon, 2002). However, high representational validity would probably not contribute to reflection since the demand for a timely response precludes taking time to reflect. Our study instead supports the conclusion that high-fidelity simulations are not necessary to facilitate learning (Kersh, 1965; Toups, et al., 2011). As mentioned in the introduction, other simulations have been used in teacher education to get students to learn to think on their feet, and to facilitate their effectiveness in applying teaching methods (Mahon, et al., 2010; Dieker et al., 2014; Hughes et al., 2015). SIMPROV did not facilitate such habitual action (Median $=11)$. This means that participants did not engage in implicit and routine-based reproductive learning that they could get from rehearsal (Schön, 1983). The design of SIMPROV was instead successful in catering for reflection by providing student teachers with scenarios, opportunities to socially interact, discuss choices, see the effects of, and play around with different leadership 
styles. The simulation provided a basis for structuring social interaction during and after simulation sessions.

The scenarios and events depicted in SIMPROV are perceived as realistic (Nordvall, Arvola \& Samuelsson, 2014; Samuelsson, 2016), which implies that it does have internal validity. This means that the simulation is constructed so that it corresponds to the real world, and student teachers can use it and learn from it (Feinstein \& Cannon, 2002). Internal validity is what makes application validity possible. We know from the evaluation of perceived knowledge improvement that the student teachers experienced that they did learn from the simulation, and different sorts of qualitative analyses of single as well as pair and triad discussions show that they do identify, discuss, and problematize key aspects of classroom management (Nordvall, Arvola \& Samuelsson, 2014; Samuelsson, 2016; Ragnemalm \& Samuelsson, 2016). All in all, this is an indication that SIMPROV does have application validity, i.e. it fulfils its purpose (Feinstein \& Cannon, 2002). However, based on the present study, we do not know anything about the transferability of knowledge from simulation to practice. This means that the external validity of the simulation remains to be tested.

\section{Future Work}

The fourth, yet unfinished iteration of SIMPROV, presents the scenario using an immersive virtual reality model of a classroom with 3D scenes populated with pupils. The 3D scenes are accompanied by the hypermedia radio theatre produced for iteration 
3. The basic content of the scenario-based simulation is preserved and detail is added by the visual design of the portrayed classroom and pupils. The prototype can be used to examine the educational effect of higher fidelity. This will require further animation as well as narrative development. Furthermore, informal comments from experienced teachers and from student teachers for the lower grades suggest that the exact wording in descriptions of events differs slightly in different age groups. However, the required domain expertise makes the adaption to other age groups a non-trivial task.

\section{Conclusions}

The design and evaluation of SIMPROV indicate that a scenario-based simulation designed as a hypermedia radio theatre worked well in supporting understanding and reflection for student teachers learning classroom management. It was successful in providing leverage for reflection, by means of catering for social interaction and discussion during and after simulation sessions.

\section{Acknowledgements}

This research has been supported by the Swedish Research Council [reference number 721-2011-4741]., and it has been conducted following the ethical requirements established by the Swedish Research Council.

\section{Conflict of Interests}

The Authors declare that there is no conflict of interest. 


\section{References}

Badiee, F. \& Kaufman, D. (2014). Effectiveness of an Online Simulation for Teacher Education. Journal of Technology and Teacher Education, 22(2), 167-186. Retrieved from https://www.learntechlib.org/p/45934/

Badiee, F., \& Kaufman, D. (2015). Design evaluation of a simulation for teacher education. SAGE Open, 5(2), 1-10. http://doi.org/10.1177/2158244015592454

Bartholdsson, Å. (2007). Med facit i hand. Normalitet, elevskap och vänlig maktutövning i två svenska skolor (Doctoral dissertation). Stockholm: Socialantropologiska institutionen, Stockholms universitet.

Baumrind, D. (1971). Current patterns of parental authority. Developmental Psychology, 4(1, Pt.2), 1-103. http://doi.org/10.1037/h0030372

Bautista, N. U. \& Boone, W. J. (2015). Journal of Science Teacher Education, 26(3): 237-262. http://doi.org/10.1007/s10972-014-9418-8

Bloom, B. S. (Ed.) (1956). Taxonomy of educational objectives: the classification of educational goals. Handbook 1, Cognitive domain. New York: David McKay.

Brophy, J. (1988). Educating teachers about managing classrooms and students.

Teaching and Teacher Education, 4(1), 1-18. https://doi.org/10.1016/0742051X(88)90020-0

Creswell, J. W., \& Clark, V. L. P. (2018). Designing and conducting mixed methods research (3rd Ed.). Thousand Oaks, CA: Sage. 
Dieker, L. A., Rodriguez, J. A., Lignugaris/Kraft, B., Hynes, M. C., \& Hughes, C. E. (2014). The potential of simulated environments in teacher education: Current and future possibilities. Teacher Education and Special Education, 37(1), 21-33. https://doi.org/10.1177/0888406413512683

Edman Stålbrandt, E. (2013). Simulerade skoldilemman: Redskap för utveckling av reflektionsförmågan? (Doctoral dissertation). Turku: Åbo Akademi. Retrieved from http://www.doria.fi/handle/10024/88876

Emmer, E. T., \& Sabornie, E. J. (2014). Handbook of classroom management (2nd ed.). New York, NY: Routledge.

Feinstein A. H., Cannon H. M. (2002). Constructs of simulation evaluation. Simulation \& Gaming, 33(4), 425-440. https://doi.org/10.1177/1046878102238606

Fu, F.-L., Su, R.-C., \& Yu, S.-C. (2009). EGameFlow: A scale to measure learners' enjoyment of e-learning games. Computers \& Education, 52(1), 101-112. https://doi.org/10.1016/j.compedu.2008.07.004

Grise, P. J., Epstein, I. I., \& Lukin, T. G. (1974). Educational Radio: A Review of the Literature. The Florida State University, Center for Educational Technology, Tallahassee, Florida. Retrieved from https://eric.ed.gov/?id=ED095904

Hand, R. J., \& Traynor, M. (2011). The Radio Drama Handbook: Audio Drama in Context and Practice. New York, NY: Continuum. 
Hughes, C. E., Nagendran, A., Dieker, L. A., Hynes, M. C., \& Welch, G. F. (2015). Applications of avatar mediated interaction to teaching, job skills and wellness. In G. Brunnett, S. Coquillart, van Liere, R., \& Váša, L. (Eds.), Virtual Realities, Lecture Notes in Computer Science, 8844 (pp. 133-146). Berlin Heidelberg: Springer. https://doi.org/10.1007/978-3-319-17043-5_8

Jones, V. (2006). How do teachers learn to be effective classroom managers? In C. M. Evertson \& C. S. Weinstein (Eds.), Handbook of classroom management. Research, practice and contemporary issues (pp. 887-908). New Jersey: Lawrence Erlbaum Associates.

Karlberg, M. (2011). Skol-Komet: Tre utvärderingar av ett program för beteendeorienterat ledarskap i klassrummet (Doctoral dissertation). Uppsala: Acta Universitatis Upsaliensis. Retrieved from http://urn.kb.se/resolve?urn=urn:nbn:se:uu:diva-134784

Kember, D., Leung, D. Y. P., Jones, A., Loke, A. Y., McKay, J., Sinclair, K., Tse, H., Webb, C., Wong, F. K. Y., Wong, M., \& Yeung, E. (2000). Development of a Questionnaire to Measure the Level of Reflective Thinking. Assessment \& Evaluation in Higher Education, 25(4), 381-395. http://dx.doi.org/10.1080/713611442

Kersh, B. Y. (1965). Classroom simulation: Further studies on dimensions of realism (Final Report Project Number 5-0848). Monmouth, OR: Teaching Research 
Division of the Oregon State System of Higher Education. Retrieved from http://files.eric.ed.gov/fulltext/ED010176.pdf

Lewin, K., Lippit, R., \& White, R. K. (1939). Patterns of aggressive behavior in experimentally created "social climates". The Journal of Social Psychology, 10(2), 271-299. http://dx.doi.org/10.1080/00224545.1939.9713366

Lewis, R., Romi, S., Katz, Y. J., \& Xing, Q. (2008). Students' reactions to classroom discipline in Australia, Israel and China. Teaching and Teacher Education, 24(3), 715-724. https://doi.org/10.1016/j.tate.2007.05.003

Mahon, J., Bryant, B., Brown, B., \& Kim, M. (2010). Using second life to enhance classroom management practice in teacher education. Educational Media International, 47(2), 121-134. http://dx.doi.org/10.1080/09523987.2010.492677

Mezirow, J. (1997). Transformative learning: Theory to practice. New directions for adult and continuing education, 74, 5-12. http://dx.doi.org/10.1002/ace.7401

Manburg, J., Moore, R., Griffin, D., \& Seperson, M. (2017). Building reflective practice through an online diversity simulation in an undergraduate teacher education program. Contemporary Issues in Technology and Teacher Education, 17(1). Retrieved from http://www.citejournal.org/volume-17/issue-1-17/currentpractice/building-reflective-practice-through-an-online-diversity-simulation-inan-undergraduate-teacher-education-program 
Moos, D. C., \& Marroquin, E. (2009). Multimedia, hypermedia, and hypertext: Motivation considered and reconsidered. Computers in Human Behavior, 26(3), 265-276. https://doi.org/10.1016/j.chb.2009.11.004

Nordvall, M., Arvola, M., \& Samuelsson, M. (2014). Exploring Simulated Provocations: Supporting Pre-service Teachers' Reflection on Classroom Management. In P. Zaphiris, \& A. Ioannou (Eds.), Learning and Collaboration Technologies, Technology-Rich Environments for Learning and Collaboration. Lecture Notes in Computer Science, 8524 (pp. 182-193). Berlin Heidelberg: Springer. https://doi.org/10.1007/978-3-319-07485-6_19

Ragnemalm, E. L., \& Samuelsson, M. (2016). Simulating variation in order to learn classroom management. Educational Media International, 53(4), 274-284. http://dx.doi.org/10.1080/09523987.2016.1254882

Rayner, C., \& Fluck, A. (2014). Pre-service teachers' perceptions of simSchool as preparation for inclusive education: a pilot study. Asia-Pacific Journal of Teacher Education, 2014, 42(3), 212-227. http://dx.doi.org/10.1080/1359866X.2014.927825

Reid, S., \& Day, D. (1942). Chapter VI: Radio and Records in Education. Review of Educational Research, 12(3), 305-322. https://doi.org/10.3102/00346543012003305 
Samuelsson, M. (2008). Störande elever korrigerande lärare: Om regler, förväntningar och lärares åtgärder mot störande flickor och pojkar i klassrummet (Doctoral dissertation). Linköping: Institutionen för beteendevetenskap och lärande, Linköpings universitet. Retrieved from http://urn.kb.se/resolve?urn=urn:nbn:se:liu:diva-10589

Samuelsson, M. (2013). Followership and leadership in different sorts of sloyd practices. Ethnography and Education, 8(1), 105-117. https://doi.org/10.1080/17457823.2013.766437

Samuelsson, M., \& Colnerud, G. (2015). Student teachers' perceptions regarding the challenges of leadership. In D. Garbett \& A. Ovens (Eds.), Teaching for tomorrow today (pp. 312-320). Auckland: International Association of Teachers and Teaching (ISATT) and Edify Ltd. Retrieved from http://urn.kb.se/resolve?urn=urn:nbn:se:liu:diva-120497

Samuelsson, M. (2016). Specialpedagogisk identifikation och problematisering av ett simulerat klassrumsledarskap. In A-L Eriksson Gustavsson, K Forslund Frykedal \& M. Samuelsson (Eds.), Specialpedagogik - i, om, för och med praktiken (pp. 116-134). Stockholm: Liber.

Schön, D. A. (1983). The reflective practitioner: how professionals think in action. New York: Basic Books. 
Toups, Z. O., Kerne, A., Hamilton, W. A., \& Shahzad, N. (2011). Zero-fidelity simulation of fire emergency response: improving team coordination learning. In Proceedings of the SIGCHI Conference on Human Factors in Computing Systems (CHI '11) (pp. 1959-1968). New York: ACM. http://dx.doi.org/ $10.1145 / 1978942.1979226$

Wedin, A-S. (2007). Lärares arbete och kunskapsbildning: Utmaningar och inviter $i$ den vardagliga praktiken (Doctoral dissertation). Linköping: Institutionen för beteendevetenskap och lärande, Linköpings universitet. Retrieved from http://urn.kb.se/resolve?urn=urn:nbn:se:liu:diva-11231

Wester, M. (2008). "Hålla ordning, men inte överordning”. Köns- och maktperspektiv på uppförandenormer i svenska klassrumskultur (Doctoral dissertation). Umeå: Svenska och samhällsvetenskapliga ämnen, Umeå universitet. Retrieved from http://urn.kb.se/resolve?urn=urn:nbn:se:umu:diva-1661 